\title{
КОМПЕТЕНТНІСНИЙ ПІДХІД У СТВОРЕННІ СТАНДАРТУ ВИЩОЇ ОСВІТИ СПЕЦІАЛЬНОСТІ “ФАРМАЦІЯ”
}

\author{
В. П. Черних, А. А. Котвіцька, С. В. Огарь \\ Національний фармацевтичний університет
}

\section{COMPETENCE APPROACH IN CREATION OF A STANDARD OF HIGHER EDUCATION IN SPECIALITY “PHARMACY”}

\author{
V. P. Chernykh, A. A. Kotvitska, S. V. Ohar \\ National University of Pharmacy
}

\begin{abstract}
Створення галузевих стандартів вищої фармацевтичної освіти нового покоління на основі компетентнісного підходу є необхідним етапом на шляху підготовки сучасного фахівця, якого потребує практична фармація.

До роботи над стандартом, крім робочої групи, визначеної наказом МОЗ України від 06.11.2015 р. № 733, були залучені фахівці практичної фармації, чия думка є невід’ємним компонентом при створенні державного стандарту, що відповідав би усім європейським вимогам. Проведено соціологічне опитування фахівців практичної фармації щодо загальних та професійних компетентностей випускника, результати якого впроваджено до стандарту вищої освіти спеціальності “Фармація”.
\end{abstract}

Creating of new generation industry standards for higher pharmaceutical education based on the competency approach is a necessary step towards a modern specialist training required in practical pharmacy. Besides the working group according to the order of Ministry of Health of Ukraine from 06.11.2015 № 733, general experts in pharmacy were involved in the standard developing and their opinion is an integral component in the state standard creation that would meet all European requirements. General pharmacy experts were interviewed in order to find out graduates' general and professional competences and its results were implemented to standard of higher education in specialty "Pharmacy".

Вступ. 3 набуттям чинності Закону України “Про вищу освіту” від 01.07.2014 р. розпочався новий етап реформування вітчизняної освітньої системи. Закон містить багато норм, апробованих у європейських університетах, але нових для українських закладів освіти [1].

Однією з головних методологічних засад нового Закону України “Про вищу освіту” є автономія закладів вищої освіти. Якщо дотепер галузеві стандарти вищої освіти визначали перелік нормативних навчальних дисциплін та обсяги їх викладання, то новий закон передбачає, що нормативний зміст підготовки здобувачів вищої освіти формуватиметься у термінах результатів навчання, а переліки навчальних дисциплін визначатимуться самими закладами освіти [1, 2, 7].

Питання розробки освітніх стандартів вищої фармацевтичної освіти є складним і різноплановим. Дискутуються питання щодо змісту освіти, проблеми співвідношення стандарту і академічних

(c) В. П. Черних, А. А. Котвіцька, С. В. Огарь свобод у процесі підготовки фахівців фармації, ідеальної моделі випускника ВНЗ, який, на думку одних, має бути “вузьким спеціалістом”, а на переконання інших - повинен стати “універсалом”, носієм фундаментальних знань.

Розробка нових стандартів вищої освіти має стратегічне завдання з удосконалення системи контролю й оцінки якості освіти та наголошує на необхідності порівняння досягнутого рівня освіти з певним еталоном, роль якого й відведена стандарту освіти [4].

Саме тому перехід до нового покоління галузевих стандартів вищої фармацевтичної освіти, на основі компетентнісного підходу, є необхідним етапом на шляху підготовки сучасного фахівця, якого потребує практична фармація.

Основна частина. Із позицій компетентнісного підходу рівень освіченості здобувачів вищої освіти визначається здатністю розв'язувати проблеми різної складності на основі наявних знань та здатності використовувати їх у практичній діяльності. 
Головними принципами компетентнісного підходу в освіті є:

- освіта для життя, успішної соціалізації в суспільстві та особистісного розвитку на основі засвоєння соціально значущих компетентностей;

- оцінювання для надання можливості здобувачеві вищої освіти планувати свої освітні результати й удосконалювати їх у процесі постійного професійного розвитку;

- організація та осмислення самостійної діяльності здобувачів вищої освіти на основі власної мотивації та відповідальності за результати;

- залучення роботодавців до оцінювання якості підготовки здобувачів вищої освіти спеціальності “Фармація” до професійної діяльності та соціальної відповідальності за результати роботи [5, 6].

Перехід до компетентнісного підходу означає переорієнтацію з процесу навчання на результати освіти в діяльнісному вимірі, зміщення акценту 3 накопичування нормативно визначених знань, умінь і навичок на формування й розвиток у здобувачів вищої освіти здатності практично діяти, застосовувати набутий досвід у конкретних ситуаціях [8].

Одним із напрямів діяльності Національного фармацевтичного університету у підготовці здобувачів вищої освіти $є$ постійне співробітництво з працівниками практичної фармації у контексті вимог сучасної інноваційної економіки.

Основними напрямками співробітництва у процесі розвитку вищої фармацевтичної освіти є участь роботодавців у формуванні освітніх програм та стандартів освіти з метою їх адаптації до потреб ринку праці; участь в оцінці якості освіти, участь практичних фахівців у процесі навчання (проведення лекцій, практичних занять тощо), створенні спільних навчально-виробничих підрозділів на підприємствах, організації навчальних практик і стажувань на підприємствах; підвищенні кваліфікації викладачів НФаУ в закладах охорони здоров’я.

У рамках співробітництва НФаУ проводить соціологічні дослідження шляхом опитування роботодавців за спеціально розробленими анкетами і спостереження самими роботодавцями за молодими фахівцями, тому що тільки в процесі роботи через деякий час після випуску можна більш повно судити про сформованість професійних компетентностей, передбачених освітніми програмами і необхідних у професійній діяльності.
Ефективність взаємодії НФаУ й роботодавців значно зростає, коли партнери-роботодавці переходять $з$ позиції сторонніх спостерігачів і виключно споживачів освітніх послуг на позицію зацікавлених учасників освітніх та інноваційних процесів, що всіляко сприяють оволодінню студентами комплексом професійних компетентностей, які відповідають вимогам сучасного ринку праці.

Для визначення загальних компетентностей було проведено соціологічне дослідження серед фахівців практичної фармації (загальна вибірка респондентів близько 470 осіб), результати якого наведено на рисунку 1. Досліджувались наступні компетентності, їх значимість у практичній діяльності: здатність застосовувати знання на практиці, здатність вчитись самостійно, вміння працювати в команді, володіння іноземною мовою, навички роботи 3 комп’ютером, здатність знаходити і аналізувати інформацію з різних джерел, здатність адаптуватися до нових ситуацій, здатність працювати самостійно, прагнення до успіху і цілеспрямованість, планування і управління часом.

Соціологічне опитування фахівців практичної фармації щодо професійних компетентностей випускника за циклами підготовки показало, що необхідно звернути увагу на недостатність фахових знань 3: медико-біологічної підготовки (68 \% роботодавців), організаційно-економічної підготовки (56 \% роботодавців), технологічної підготовки (18 \% роботодавців), хімічної підготовки (12% роботодавців).

При формуванні професійних компетентностей у розробці нового стандарту вищої освіти за спеціальністю “Фармація” необхідно працювати над реалізацією позиції потенційних роботодавців лідерів фармацевтичної галузі, що зацікавлені у підвищенні якості навчання.

Висновки. На сучасному етапі розвитку освіти компетентнісний підхід - лише один із чинників, що сприяють модернізації змісту освіти, який доповнює низку освітніх інновацій зі збереженням класичних підходів у вищій фармацевтичній освіті. Реалізація цього підходу грунтується на розумінні, що прогрес людства залежить не стільки від економічного зростання, скільки від рівня розвитку особистості та передбачає необхідність переходу від кваліфікації, яку фахівець здобуває один раз і назавжди, до компетентності, яка дозволяє мобільно удосконалювати професійну діяльність, зумовлену соціально-економічними 


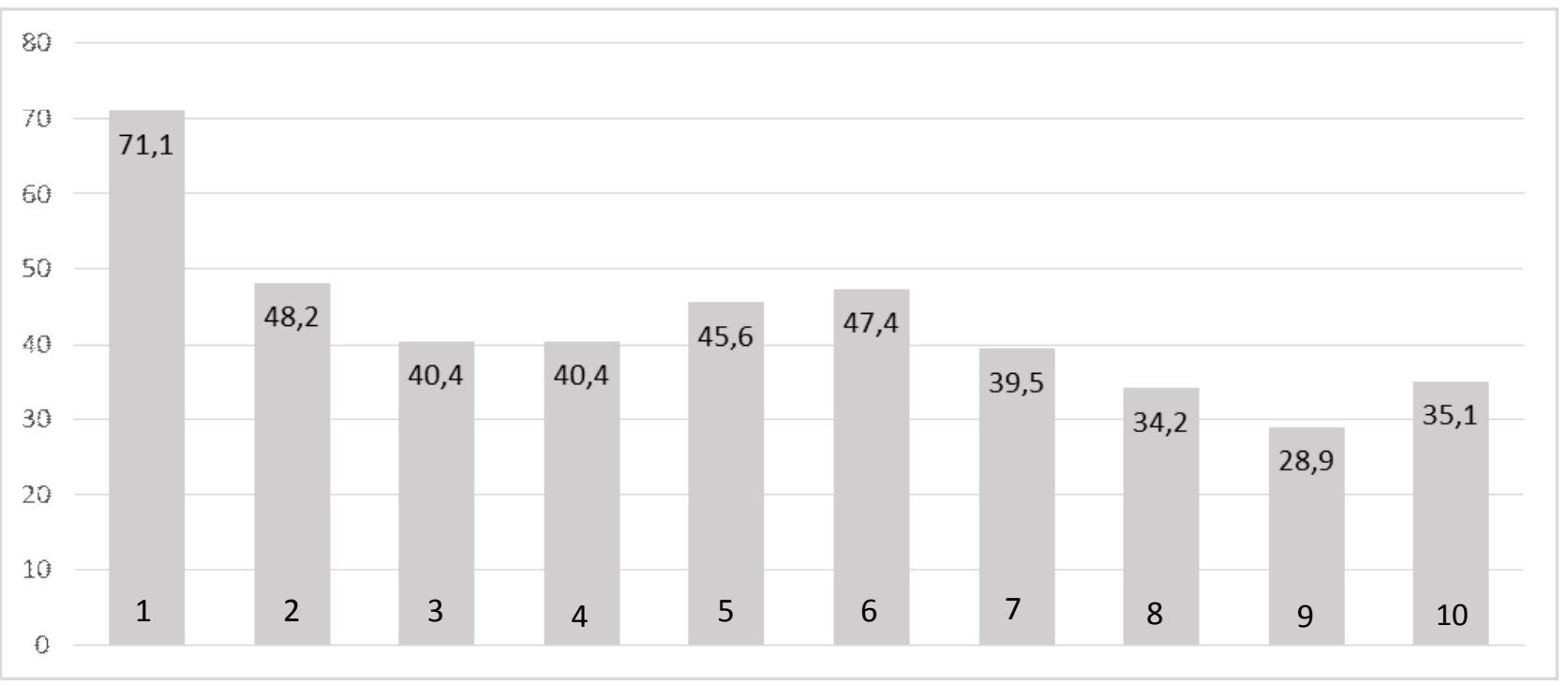

Рис. 1. Значущість загальних компетентностей у фаховій діяльності провізора:

1. Здатність застосовувати знання на практиці.

2. Здатність вчитись самостійно.

3. Вміння працювати в команді.

4. Володіння іноземною мовою.

5. Навички роботи з комп’ютером.

6. Здатність знаходити і аналізувати інформацію з різних джерел.

7. Здатність адаптуватися до нових ситуацій.

8. Здатність працювати самостійно.

9. Прагнення до успіху і цілеспрямованість.

10. Планування і управління часом.

змінами, динамікою ринку праці, концепцією Болонського процесу.

Запровадження державного стандарту спеціальності “Фармація”, створення на його основі освіт-

\section{Список літератури}

1. Закон України “Про вищу освіту” [Електронний ресурс]. - Режим доступу до ресурсу : http://zakon4.rada. gov.ua/laws/show/1556-18.

2. Національна рамка кваліфікацій [Електронний ресурс]. - Режим доступу до ресурсу : http://zakon4.rada. gov.ua/laws/show/1341- 2011-п.

3. Рашкевич Ю. М. Болонський процес та нова парадигма вищої освіти / Ю. М. Рашкевич. - Львів : Львівська політехніка, 2014. - 168 с.

4. Розвиток системи забезпечення якості вищої освіти в Україні: інформаційно-аналітичний огляд / [Т. Добко, I. Золотарьова, С. Калашнікова та ін.] ; за заг. ред. С. Калашнікової та В. Лугового. - К. : ДП “НВЦ “Пріоритети”, 2015. - 84 с.

5. Розроблення освітніх програм. Методичні рекомендації / В. М. Захарченко, В. І. Луговий, Ю. М. Рашкевич, Ж. В. Таланова ; за ред. В. Г. Кременя. - К. : ДП “НВЦ “Пріоритети”, 2014. - 120 с. ніх програм з визначеними результатами навчання сприятимуть підвищенню якості вищої фармацевтичної освіти.

6. Стандарти і рекомендації щодо забезпечення якості в Європейському просторі вищої освіти (ESG). - K. : ТОВ “ЦС”, 2015. - 32 с.

7. Common learning outcomes / competences for the bachelor of medicine in europe [Електронний ресурс]. Режим доступу до ресурсу : http://medine2.com/Public/ docs/outputs/wp4/DV4.14.1_Summary\%20Brochure\%20 -\%20Tuning\%201st\%20Cycle\%20Degrees\%20in\%20 Medicine.pdf.

8. Cumming A. The Tuning Project (Medicine) : Learning Outcomes/ Competences for Undergraduate Medical Education in Europe [Електронний ресурс] / A. Cumming, M. Ross. - Режим доступу до ресурсу : http://www.umed. pl/procesbolonski/materialy/tuning\%20_project.pdf.

Отримано 05.04.16 